\title{
Communication in healthcare as the subject of research. A narrative review of 2013-2017 literature
}

\author{
Komunikacja w opiece medycznej jako przedmiot badań naukowych. \\ Przegląd narracyjny literatury z lat 2013-2017
}

\author{
Department of Health Psychology, Faculty of Health Sciences, Jagiellonian University Medical College, Krakow, Poland \\ Correspondence: Maciej Załuski, Instytut Pielęgniarstwa i Położnictwa, ul. Kopernika 25, 31-501 Kraków, tel.: +48 609845 542, e-mail: maciej.zaluski@uj.edu.pl \\ Maciej Załuski, Institute of Nursing and Midwifery, Kopernika 25, 31-501 Krakow, Poland, tel.: + 48609845 542, e-mail: maciej.zaluski@uj.edu.pl
}

Abstract The growing knowledge of medical communication is associated with conducting scientific research. The purpose of this analysis was to review scientific literature in the field of research on interpersonal communication between a physician and a patient. We conducted a review of 2013-2017 worldwide scientific literature concerning research on communication in healthcare. The searching strategy encompassed three databases and three search engines. When searching for collections of articles, a combination of Medical Subject Headings (MeSH) words: "patient," "physician," "communication," "measurement" was used. The result was 29 empirical articles. The topics of works included a discussion on specific issues concerning communication with patients suffering from various diseases, an analysis of procedures for involving patients in making health-related decisions, presentation of research findings on the effectiveness of communication in prevention and treatment in adults, and a psychometric analysis of tools used to measure the interpersonal communication process in healthcare. There is no randomised research showing directional relationships between the types of communication used and changes in patient behaviour, and the applied methods and research tools require further improvement. What is also required in clinical practice is the popularisation of good communication practices by organising training sessions for physicians and patients.

Keywords: physician-patient relations, interpersonal communication, empirical research

Streszczenie Gromadzenie wiedzy na temat komunikacji medycznej jest związane z prowadzeniem badań naukowych. Celem przedstawionej w artykule analizy był przegląd literatury naukowej w dziedzinie badań nad komunikacją interpersonalną pomiędzy lekarzem a pacjentem. Autorzy dokonali przeglądu piśmiennictwa naukowego dotyczącego badań nad komunikacją w ochronie zdrowia opublikowanego na świecie w latach 2013-2017. Strategia przyjęta do wyszukiwana artykułów objęła zastosowanie trzech baz danych i trzech wyszukiwarek naukowych. Do przeglądania zbioru artykułów wykorzystano kombinację słów pochodzących z języka informacyjno-wyszukiwawczego MeSH (Medical Subject Headings): "pacjent”, „lekarz”, „komunikacja”, „pomiar”. W rezultacie uzyskano 29 artykułów empirycznych. Tematyka prac opisanych w artykułach obejmowała: zagadnienia specyfiki komunikowania się z pacjentami cierpiącymi ze względu na różnorakie choroby somatyczne, analizę procedur służących angażowaniu pacjentów w podejmowanie decyzji prozdrowotnych, prezentację wyników badań nad efektywnością komunikacyjną w zakresie profilaktyki i leczenia osób dorosłych, analizę właściwości psychometrycznych narzędzi służących do pomiaru procesu komunikowania się interpersonalnego w służbie zdrowia. Brak jest zrandomizowanych badań ukazujących zależności kierunkowe pomiędzy stosowanymi rodzajami komunikacji a zmianami zachowań pacjentów, zastosowane metody i narzędzia badawcze wymagają dalszych prac doskonalących. W praktyce klinicznej wymagana jest popularyzacja dobrych praktyk komunikacyjnych poprzez organizowanie sesji szkoleniowych dla lekarzy i pacjentów.

Słowa kluczowe: relacja lekarz-pacjent, komunikowanie się interpersonalne, badania empiryczne 


\section{INTRODUCTION}

A lthough communication between a patient and a physician is a natural element of diagnosis and treatment, it is not easy to define or scientifically measure it. According to the principle that a physician should focus on the patient and consider the importance attributed to the disease, communication is the key tool to understand an ill person and their condition. Communication takes place in the course of treatment when the disease is diagnosed, the health-related decisions are made together and their execution is monitored, helping to mitigate the negative emotions of the patient evoked by the disease and triggering positive emotions associated with the will to get better. The main goals of patient-oriented communication are considered to be: 1) exchange of information, 2) support of patient's independence, 3) management of their insecurity and other emotions, 4) making health-related decisions together, and strengthening the physician-patient relationship (Street et al., 2009). Therefore, communication skills have been considered as one of the key elements of the general social skills of physicians, being one of the six competences expected from a practising medical professional (patient care; medical knowledge; practice-based learning and improvement; professionalism; interpersonal skills and communication and systems-based practice) (Batalden et al., 2002). Some communication behaviours expected of a physician are well-known and include: listening carefully, conveying information in an easy-to-understand manner, the organisation providing sufficient time for conversation, showing respect and empathy, and considering the disease from the patient's perspective. However, the results of a pilot research conducted in the European Union member states showed a low level of physician-patient communication (Duffy et al., 2004).

The conducted research showed the relationships between professional medical communication and the level of patient satisfaction, physical health status, trust in the physician, general vitality and emotional well-being (Zill et al., 2014). Many publications on communication in healthcare emphasise the lack of documented, randomised clinical research to confirm the existence of the above-mentioned relationships and their directions, and there are no reliable tools to measure such variables (Clayman et al., 2016; Phillips et al., 2016; Zill et al., 2014). The paths linking the elements of the communication process with treatment outcomes are not sufficiently explored, and the research does not include all intermediate variables (Patel and Wheeler, 2014; Street, 2013). Reliable knowledge of patient-physician communication is still a challenge for scientific research.

\section{AIM OF THE STUDY}

The aim of the study was to learn about the issues and scope of empirical research on interpersonal communication between physicians and patients. The following research question was posed: are there empirical studies in the discussed topic and what are their goals? For this purpose, a narrative review of literature published in the years 2013-2017 was used. The reason for narrowing the publications to those published in the last five years was to capture up-to-date research problems. A broad question was put forth to pre-study the basic issues of physician-patient communication. A qualitative analysis was conducted using variable criteria for the evaluation of articles.

\section{MATERIAL AND METHODS}

\section{Strategy used to select articles for analysis}

The literature presenting research on patient-physician communication was reviewed. When searching the collections of articles, the combination of Medical Subject Headings (MeSH) words: "patient," "physician," "communication," "measurement" was used, each word being separated by the AND Boolean operator. We used the following Internet search engines: Web of Science, PubMed and Ovid, and databases: EBSCO, MEDLINE and EMBASE.

\section{Inclusion criteria}

The articles selected for research purposes had to meet the following criteria:

1. paper written in the years 2013-2017 as a full-text article with an abstract, and published in English in a peerreviewed journal;

2. communication between adult patients and physicians, an empirical article;

3. broad definition of communication (verbal, non-verbal, behaviour, interpersonal interactions or skills, as an element of medical decision-making processes);

4. communication between adult patients (over 18 years old) and physicians;

5. empirical research used the method of a questionnaire, structured interview and observation as well as an analysis of the conversation text saved in a digital form.

\section{Exclusion criteria}

The following exclusion criteria were adopted:

1. article concerns improving communication skills of medical students and healthcare professionals, and refers to the effectiveness of the training conducted;

2. article concerns communication between healthcare units.

The search yielded a total of 3,928 records. After deleting duplicated records, there were 734 papers left with indexed keywords included in the titles. In the next stage, we focused on the analysis of abstracts and keywords of the papers meeting the inclusion criteria. The third step involved 
an analysis of the contents of the articles to check if they meet the exclusion criteria. This step left the authors with 29 papers.

The empirical papers were analysed for the design of research, applied research methods, research problems, variables and conclusions, postulates and limitations.

\section{RESULTS AND DISCUSSION}

The authors of 29 analysed manuscripts came from 11 countries. The highest number of papers were published in years 2013-2015 and 2017 (six in each year), while the fewest in 2016 (five papers).

Scientific articles were systematised based on the information about the authors of papers, the design of research, applied research methods, research problems, variables and limitations. The articles discussed the results of two types of research: 1) applied research - the use of knowledge about interpersonal communication in the field of prophylaxis and treatment of adults (20 articles), and 2) reports from research evaluating the psychometric parameters of scientific tools (nine articles). The articles from the first group presented the results of scientific projects, mostly of an observational nature (18 articles; latest: Henry et al., 2016; Kurlander et al., 2017; Landmark et al., 2017; Li et al., 2017; Menendez et al., 2017), while two cases were of experimental or quasi-experimental nature (Ballo et al., 2017; Dillon et al., 2017). Two types of research procedures were used. The most common research was of correlational nature (14 papers) (latest articles: Henry et al., 2016; Landmark et al., 2017; Li et al., 2017; Menendez et al., Weeger and Farin, 2017), including one longitudinal research (Maly et al., 2015), while exploration papers were less numerous (five publications; latest: Calpin et al., 2017; Wikström et al., 2016). In most research projects (ten papers), mixed methods were applied by the authors, who used self-descriptive scales with an audio recording (Dillon et al., 2017; Essers et al., 2013; Henry et al., 2016) as well as a tests (Menendez et al., 2017), an analysis of official notes and other medical documents (Li et al., 2017; Schwartz et al., 2015), a video recording and observation (Landmark et al., 2017), an interview (Capone, 2016; Gigon et al., 2015), an interview and self-descriptive questionnaire (Adams et al., 2016; Essers et al., 2013; Maly et al., 2015) to measure the variables. Six research studies used only the method of structured interview (Book et al., 2013; Calpin et al., 2017; Mazor et al., 2013; Patel and Wheeler, 2014; Sweeny et al., 2013; Wikström et al., 2016) and the method of research with self-descriptive questionnaires (Ballo et al., 2017; Quigley et al., 2014; Weeger and Farin, 2017).

Research problems referred to five thematic groups (Tab. 1):

1. sources of problems in communication embedded in various treatment situations and their consequences;

2. stimulation of patient's involvement in making decisions on health-related behaviours;
3. impact of the quality of communication on the patient's behaviour and mental state;

4. specificity of the communication of doctors with various specialisations;

5. an assessment of psychometric parameters of nine research tools.

The research studies were used to formulate conclusions on the factors affecting the quality of communication (Tab. 2).

The limitations of the conducted research primarily refer to the applied methodology. What was commonly noticed was the small size of the study group, as seen in seven articles (latest: Ballo et al., 2017; Henry et al., 2016; Menendez et al., 2017), its homogeneity (Li et al., 2017), and non-randomised selection of subjects (Adams et al., 2016; Sweeny et al., 2013). Limitations were reported with reference to the applied method - errors typical of self-descriptive methods, including social desirability response biases, bias of common method variance, in seven articles (latest: Dillon et al., 2017; Li et al., 2017) and difficulties with controlling hidden variables, an insufficient number of variables, as well as no possibility to indicate the direction of correlations, in nine articles (latest: Adams et al., 2016; Dillon et al., 2017; Menendez et al., 2017). What was also noted were errors that might have occurred during the analysis of received results as well as the impact of the diagnosis and treatment stage on the form of results (Mazor et al., 2013).

It was concluded that the research on the processes of mutual communication between clinicians should be continued (Adams et al., 2016), the tools for measuring and monitoring the exchange of information between patient and physician should be improved (nine articles, latest: Ballo et al., 2017; Weeger and Farin, 2017; Wikström et al., 2016), and research that would help learn about factors affecting the patient's involvement in making decisions on treatment should be conducted (Dillon et al., 2017; Landmark et al., 2017; Menendez et al., 2017), training sessions should be organised to improve the competencies of physicians in terms of starting conversations on difficult subjects (Book et al., 2013; Gigon et al., 2015; Henry et al., 2016; Quigley et al., 2014; Sweeny et al., 2013).

\section{CONCLUSION}

The paper discusses 29 articles on scientific research in the field of interpersonal communication in healthcare. The authors of papers point to a number of shortages, such as a small number of research tools with the required psychometric parameters, a limited number of research studies in random samples, or the lack of appreciation shown by the management of healthcare units for interpersonal communication in the course of treatment both during hospitalisation and further treatment in outpatient clinics. Many recent research studies have focused on identifying factors that hinder 


\begin{tabular}{|c|c|}
\hline Authors & Topic \\
\hline & 1. Difficulties in patient-physician communication \\
\hline Essers et al., 2013 & Considering contextual factors in the assessment of the quality of the general practitioner's communication level \\
\hline Sweeny et al., 2013 & Differences in preferences with regard to conveying bad news between patients and physicians \\
\hline Patel and Wheeler, 2014 & Difficulties in initiating conversations about the costs of treatment with asthmatics \\
\hline Gigon et al., 2015 & Lack of knowledge on advance directives among patients waiting for an operation \\
\hline Schwartz et al., 2015 & $\begin{array}{l}\text { Differences in the assessment of treatment results, mental health state and satisfaction with treatment between patients and surgeons } \\
\text { after the completion of treatment }\end{array}$ \\
\hline Wikström et al., 2016 & Differences in postoperative pain assessment between patients and healthcare employees \\
\hline Henry et al., 2016 & Negotiating the doses of opioid pain medications by general practitioners \\
\hline \multirow[t]{2}{*}{ Menendez et al., 2017} & Insufficient patient's knowledge about health issues, and the number of questions asked of an orthopaedic surgeon \\
\hline & 2. Issues related to motivating patients to participate in making health-related decisions \\
\hline Landmark et al., 2017 & Methods of shaping the patient's preferences and involvement in the treatment process \\
\hline Li et al., 2017 & Effectiveness of the physicians' actions aimed at making patients with chronic liver disease aware of the importance of screening tests \\
\hline \multirow[t]{2}{*}{ Dillon et al., 2017} & The most effective interventions enhancing communication and shared decision making with regard to treatment \\
\hline & 3. Medical communication and the quality of the patient's life \\
\hline Book et al., 2013 & Role of "psycho-oncological treatment" when physicians start a conversation with patients about their psychosocial problems \\
\hline Maly et al., 2015 & Quality of life in women with a small income and low social status undergoing cancer treatment \\
\hline Capone, 2016 & $\begin{array}{l}\text { Effectiveness of patient communication and signs of respect on the part of physicians, and the mental health of patients treated } \\
\text { in outpatient clinics }\end{array}$ \\
\hline Adams et al., 2016 & $\begin{array}{l}\text { Patient's satisfaction with medical care and the feeling of safety related to the continuity of communication between the hospital } \\
\text { and the general practitioner }\end{array}$ \\
\hline \multirow[t]{2}{*}{ Weeger and Farin, 2017} & Quality of life and following orders among patients undergoing rehabilitation for cardiac reasons \\
\hline & 4. Specific nature of communication of physicians with various specialisations \\
\hline Mazor et al., 2013 & Views of oncological patients and members of their families on communication with physicians in the course of treatment \\
\hline \multirow[t]{2}{*}{ Quigley et al., 2014} & Basic elements of medical communication as assessed by patients treated by physicians of various specialisations \\
\hline & 5. Validation of the physician-patient communication standardised instruments \\
\hline Wachira et al., 2013 & PPCBS - Physician-Patient Communication Behaviors Scale \\
\hline Elwyn et al., 2013 & CollaboRATE - Patient-Reported Measure of the Shared Decision-Making Process \\
\hline Scholl et al., 2014 & 4HCS (Four Habits Coding Scheme), German version \\
\hline Antoine et al., 2014 & $\mathrm{CSI}$ - Communication and Sharing Information scale \\
\hline Solari et al., 2014 & COSM-S - The Comunicazione medico-paziente nella Sclerosi Multipla - Shortened \\
\hline Burt et al., 2014 & GCRS - Global Consultation Rating Scale \\
\hline Sabee et al., 2015 & PISCH - The Process of Interactional Sensitivity Coding in Healthcare \\
\hline Barr et al., 2015 & Observer OPTION5 - Observing Patient Involvement in Decision Making \\
\hline Amati and Hannawa, 2015 & CEOLC - Contradictions in End-of-Life Communication \\
\hline Mazor et al., 2016 & PACE - Patient Assessment of cancer Communication Experience \\
\hline Kurlander et al., 2017 & PPRS - Patient-Physician Relationship Scale \\
\hline
\end{tabular}

Tab. 1. Research problems

the communication process on the part of the patient, physician and organisation, and those responsible for increasing patient's involvement in making decisions about treatment. Although the first papers on patient-physician communication were published nearly 63 years ago (paternalistic model of doctor-patient communication by Szasz and Hollender, 1956), and the knowledge gained from that time provided a number of models, the matters discussed here still pose problems when it comes to the rigorous requirements of scientific research methodologies.

The narrative review of literature shows that scientific articles are dominated by research reports examining the communication process primarily from the point of view of the patient's good (commitment to the course of treatment, quality of life, satisfaction with treatment, self-assessment of health). It is clearly visible that there are no studies looking at the quality of interpersonal communication, sources of overload and occupational stress. There are currently no standardised tools to measure the physician-patient communication process in Poland.

\section{LIMITATIONS}

A strength of this review is the detailed electronic search strategy. The primary limitation of the conducted analysis is the omission of papers included in the bibliographies of the analysed articles. Their inclusion would probably increase the number of manuscripts subject to analysis and help better illustrate the matters at hand. 


\begin{tabular}{|l|l|}
\hline Tested variables & Source \\
\hline $\begin{array}{l}\text { The patient's knowledge of health and disease, education and communication skills } \\
\text { of the patient correlate with the number of questions asked, assessment of the } \\
\text { postoperative pain level and treatment outcomes; undertaking behaviours beneficial } \\
\text { for health; quality of communication with the physician }\end{array}$ & $\begin{array}{l}\text { Ballo et al., 2017; Li et al., 2017; Menendez et al., 2017; Schwartz et al., 2015; } \\
\text { Wikström et al., 2016 }\end{array}$ \\
\hline $\begin{array}{l}\text { The clinical competences of the physician and the type of clinical specialisation affect } \\
\text { the assessment of postoperative pain and the assessment of the physician }\end{array}$ & Quigley et al., 2014; Wikström et al., 2016 \\
\hline $\begin{array}{l}\text { An effective exchange of information and a positive physician-patient relationship } \\
\text { satisfy the expectations of cancer patients and their families }\end{array}$ & Mazor et al., 2013 \\
\hline $\begin{array}{l}\text { Negotiating doses of analgesics, conversations about treatment costs, a conversation } \\
\text { on advanced directives, a failure to consider contextual variables is the source } \\
\text { of communication problems for the physician }\end{array}$ & Essers et al., 2013; Gigon et al., 2015; Henry et al., 2016; Patel and Wheeler, 2014 \\
\hline $\begin{array}{l}\text { There are differences in the severity of symptoms, goals and the course of treatment } \\
\text { in the assessment of patients and physicians }\end{array}$ & Calpin et al., 2017; Schwartz et al., 2015; Sweeny et al., 2013; Weeger and Farin, 2017 \\
\hline $\begin{array}{l}\text { The lack of a flow of information between doctors in hospitals and outpatient clinics } \\
\text { has a negative effect on patient's satisfaction, feeling of safety, health assessment } \\
\text { and quality of life }\end{array}$ & Adams et al., 2016; Book et al., 2013; Maly et al., 2015; Press et al., 2015 \\
\hline $\begin{array}{l}\text { Following preliminary hypotheses regarding the patient and applying incompatible } \\
\text { procedures have a negative effect on the patient's involvement in the treatment }\end{array}$ & Dillon et al., 2017; Landmark et al., 2017 \\
\hline
\end{tabular}

Tab. 2. Research study conclusions: factors affecting the course and quality of patient-physician communication process

Another limitation arises from the sources used for retrieving articles. The use of the PsycINFO database would allow us reaching articles published in psychological journals. Searching for the combination of term using the Boolean AND operator was likely to miss a number of the relevant papers. The OR operator could be an effective search strategy. Due to the wide selection of articles for analysis, it was not possible to apply restrictive principles of systematic review. This fact contributed to the use of biased selection and assessment methods.

\section{Conflict of interest}

The authors report no conflicts of interest in this work.

\section{References}

Adams DR, Flores A, Coltri A et al.: A missed opportunity to improve patient satisfaction? Patient perceptions of inpatient communication with their primary care physician. Am J Med Qual 2016; 31: 568-576.

Amati R, Hannawa AF: Physician-perceived contradictions in end-oflife communication: toward a self-report measurement scale. Health Commun 2015; 30: 241-250.

Antoine E, Delmas C, Coutherut J et al.: Development and psychometric testing of a scale assessing the sharing of medical information and interprofessional communication: the CSI scale. BMC Health Serv Res 2014; 14: 126.

Ballo P, Milli M, Slater C et al.: Prospective validation of the Decalogue, a set of doctor-patient communication recommendations to improve patient illness experience and mood states within a hospital cardiologic ambulatory setting. Biomed Res Int 2017; 2017: 2792131.

Barr PJ, O'Malley AJ, Tsulukidze M et al.: The psychometric properties of Observer OPTION 5 , an observer measure of shared decision making. Patient Educ Couns 2015; 98: 970-976.

Batalden P, Leach D, Swing S et al.: General competencies and accreditation in graduate medical education. Health Aff (Millwood) 2002; 21: 103-111.

Book K, Dinkel A, Heinrich G et al.: The effect of including a 'psychooncological statement' in the discharge summary on patientphysician communication: a randomized controlled trial. Psychooncology 2013; 22: 2789-2796.
Burt J, Abel G, Elmore $\mathrm{N}$ et al.: Assessing communication quality of consultations in primary care: initial reliability of the Global Consultation Rating Scale, based on the Calgary-Cambridge Guide to the Medical Interview. BMJ Open 2014; 4: e004339.

Calpin P, Imran A, Harmon D: A comparison of expectations of physicians and patients with chronic pain for pain clinic visits. Pain Pract 2017; 17: 305-311.

Capone V: Patient communication self-efficacy, self-reported illness symptoms, physician communication style and mental health and illness in hospital outpatients. J Health Psychol 2016; 21: 1271-1282.

Clayman ML, Bylund CL, Chewning B et al.: The impact of patient participation in health decisions within medical encounters: a systematic review. Med Decis Making 2016; 36: 427-452.

Dillon EC, Stults CD, Wilson C et al.: An evaluation of two interventions to enhance patient-physician communication using the observer OPTION ${ }^{5}$ measure of shared decision making. Patient Educ Couns 2017; 100: 1910-1917.

Duffy FD, Gordon GH, Whelan G et al.; Participants in the American Academy on Physician and Patient's Conference on Education and Evaluation of Competence in Communication and Interpersonal Skills: Assessing competence in communication and interpersonal skills: the Kalamazoo II report. Acad Med 2004; 79: 495-507.

Elwyn G, Barr PJ, Grande SW et al.: Developing CollaboRATE: a fast and frugal patient-reported measure of shared decision making in clinical encounters. Patient Educ Couns 2013; 93: 102-107.

Essers G, Kramer A, Andriesse B et al.: Context factors in general practitioner-patient encounters and their impact on assessing communication skills - an exploratory study. BMC Fam Pract 2013; 14; 65 .

Gigon F, Merlani P, Ricou B: Advance directives and communication skills of prehospital physicians involved in the care of cardiovascular patients. Medicine (Baltimore) 2015; 94: e2112.

Henry SG, Chen M, Matthias MS et al.: Development of the Chronic Pain Coding System (CPCS) for characterizing patient-clinician discussions about chronic pain and opioids. Pain Med 2016; 17: 1892-1905.

Kurlander JE, Chey WD, Morris CB et al.: Development and validation of the Patient-Physician Relationship Scale among patients with irritable bowel syndrome. Neurogastroenterol Motil 2017; 29: 1-8.

Landmark AMD, Ofstad EH, Svennevig J: Eliciting patient preferences in shared decision-making (SDM): comparing conversation analysis and SDM measurements. Patient Educ Couns 2017; 100: 2081-2087.

Li DJ, Park Y, Vachharajani N et al.: Physician-patient communication is associated with hepatocellular carcinoma screening in chronic liver disease patients. J Clin Gastroenterol 2017; 51: 454-460. 
Maly RC, Liu Y, Liang LJ et al.: Quality of life over 5 years after a breast cancer diagnosis among low-income women: effects of race/ethnicity and patient-physician communication. Cancer 2015; 121 : 916-926.

Mazor KM, Beard RL, Alexander GL et al.: Patients' and family members' views on patient-centered communication during cancer care. Psychooncology 2013; 22: 2487-2495.

Mazor KM, Street RL Jr, Sue VM et al.: Assessing patients' experiences with communication across the cancer care continuum. Patient Educ Couns 2016; 99: 1343-1348.

Menendez ME, van Hoorn BT, Mackert M et al.: Patients with limited health literacy ask fewer questions during office visits with hand surgeons. Clin Orthop Relat Res 2017; 475: 1291-1297.

Patel MR, Wheeler JR: Physician-patient communication on cost and affordability in asthma care. Who wants to talk about it and who is actually doing it. Ann Am Thorac Soc 2014; 11: 1538-1544.

Phillips NM, Street M, Haesler E: A systematic review of reliable and valid tools for the measurement of patient participation in healthcare. BMJ Qual Saf 2016; 25: 110-117.

Press MJ, Gerber LM, Peng TR et al.: Postdischarge communication between home health nurses and physicians: measurement, quality, and outcomes. J Am Geriatr Soc 2015; 63: 1299-1305.

Quigley DD, Elliott MN, Farley DO et al.: Specialties differ in which aspects of doctor communication predict overall physician ratings. J Gen Intern Med 2014; 29: 447-454.

Sabee CM, Koenig CJ, Wingard L et al.: The process of interactional sensitivity coding in health care: conceptually and operationally defining patient-centered communication. J Health Commun 2015; 20: 773-782.

Scholl I, Nicolai J, Pahlke S et al.: The German version of the Four Habits Coding Scheme - association between physicians' communication and shared decision making skills in the medical encounter. Patient Educ Couns 2014; 94: 224-229.
Schwartz CE, Ayandeh A, Finkelstein JA: When patients and surgeons disagree about surgical outcome: investigating patient factors and chart note communication. Health Qual Life Outcomes 2015; 13: 161.

Solari A, Grzeda M, Giordano A et al.; SIMS-Trial, SIMS-Practice and Agorà studies: Use of Rasch analysis to refine a patientreported questionnaire on satisfaction with communication of the multiple sclerosis diagnosis. Mult Scler 2014; 20: 1224-1233.

Street RL Jr: How clinician-patient communication contributes to health improvement: modeling pathways from talk to outcome. Patient Educ Couns 2013; 92: 286-291.

Street RL Jr, Makoul G, Arora NK et al.: How does communication heal? Pathways linking clinician-patient communication to health outcomes. Patient Educ Couns 2009; 74: 295-301.

Sweeny K, Shepperd JA, Han PK: The goals of communicating bad news in health care: do physicians and patients agree? Health Expect 2013; 16: 230-238.

Szasz TS, Hollender MH: A contribution to the philosophy of medicine; the basic models of the doctor-patient relationship. AMA Arch Intern Med 1956; 97: 585-592.

Wachira J, Middlestadt S, Reece M et al.: Psychometric assessment of a physician-patient communication behaviors scale: the perspective of adult HIV patients in Kenya. AIDS Res Treat 2013; 2013: 706191.

Weeger S, Farin E: The effect of the patient-physician relationship on health-related quality of life after cardiac rehabilitation. Disabil Rehabil 2017; 39: 468-476.

Wikström L, Eriksson K, Fridlund B et al.: Healthcare professionals' descriptions of care experiences and actions when assessing postoperative pain - a critical incident technique analysis. Scand J Caring Sci 2016; 30: 802-812.

Zill JM, Christalle E, Müller E et al.: Measurement of physicianpatient communication - a systematic review. PLoS One 2014; 9: e112637. 